\title{
Pengaruh Kualitas Layanan Terhadap Citra Destinasi Desa Wisata Ketingan Dengan Electronic Word Of Mouth Sebagai Variabel Pemediasi
}

\author{
Chriswardana Bayu Dewa, S.E.,M.M. \\ Universitas Bina Sarana Informatika \\ E-mail : chriswardana.chb@bsi.ac.id
}

\begin{abstract}
Ketingan Tourism Village is located in Tirtoadi Village, Mlati, Sleman, Yogyakarta which has the potential as one of the village's tourist destination destinations in Yogyakarta. However, the development of the village tourism is still not optimal, especially in terms of product socialization and marketing strategies that have not been prospective, so there needs to be an effort to increase the attractiveness of village tourism. This research presents that, there are many other factors that can influence consumer decisions in traveling, but the source of individual information turns out to be the main influence that shapes one's perception in visiting a tourist area. The research subjects are tourists who are members of the Yogyakarta backpacker facebook group. The sample selection uses a non-probability sampling method consisting of 120 people. Hypotheses are tested using Structural Equation Model (SEM). This study found that service quality has a positive effect on e-word of mouth, e-word of mouth has a positive effect on destination image, service quality has a positive effect on destination image and e-word of mouth can fully mediate a positive relationship between service quality with image destination.
\end{abstract}

\section{Keyword: Service Quality, Destination Image, e-Word of Mouth}

Abstrak - Desa Wisata Ketingan terletak di Desa Tirtoadi, Mlati, Sleman, Yogyakarta memiliki potensi sebagai salah satu tujuan destinasi obyek wisata desa yang ada di Yogyakarta. Akan tetapi pengembangan desa wisata tersebut masih belum maksimal khususnya dalam hal sosialisasi produk dan strategi pemasaran yang belum prospektif sehingga perlu adanya upaya untuk meningkatkan daya tarik wisata desa. Penelitian ini menyajikan bahwa, banyak sekali faktor lain yang dapat mempengaruhi keputusan konsumen dalam berwisata, tetapi sumber informasi individual ternyata menjadi pengaruh utama yang membentuk persepsi seseorang dalam mengunjungi suatu daerah wisata. Subyek penelitian adalah para wisatawan yang tergabung dalam grup facebook backpacker Yogyakarta. Pemilihan sampel menggunakan metode non-probability sampling yang terdiri dari 120 orang. Hipotesis diuji dengan menggunakan Structural Equation Model (SEM). Penelitian ini menemukan bahwa kualitas pelayanan berpengaruh positif terhadap e-word of mouth, e-word of mouth berpengaruh positif terhadap citra destinasi, kualitas layanan berpengaruh positif terhadap citra destinasi dan e-word of mouth secara penuh dapat memediasi hubungan positif antara kualitas layanan terhadap citra destinasi.

Kata Kunci: Kualitas Layanan, Citra Destinasi, e-Word of Mouth

\subsection{Latar Belakang}

Dewasa ini sektor pariwisata di Indonesia mengalami perkembangan yang positif. Meningkatnya pemasukan dari sektor pariwisata bagi suatu daerah menunjukkan bahwa semua pihak yang mengambil bagian dalam industri pariwisata wajib untuk melakukan pengelolaan yang profesional terhadap pariwisata daerahnya. Kapabilitas suatu daerah untuk mengembangkan dan mengelola potensi objek-objek wisata yang dimiliki akan berdampak pada meningkatnya keuntungan daerah tersebut. Yogyakarta menjadi salah satu tujuan wisata yang diminati oleh turis mancanegara maupun turis lokal. Menurut Kompas.com, Dinas Pariwisata Pemerintah Provinsi Daerah Istimewa Yogyakarta memiliki target pada tahun 2019 jumlah wisatawan ke Yogyakarta mencapai 3,47 juta wisatawan. Yogyakarta memiliki obyek wisata yang terkenal dikalangan turis mancanegara maupun turis lokal, yaitu Kraton Yogyakarta, Tamansari, Malioboro, Gunung Merapi, Candi Mendut, pantai Parang Tritis, Pantai Baron, Goa Pindul, Tebing Breksi, Hutan Pinus dan lain-lain yang menjadi destinasi wisata unggulan.

Di Yogyakarta terdapat beberapa desa yang memiliki potensi wisata yang baik. Ada yang sudah tergolong unggul, tetapi ada juga yang masih perlu dikembangkan. Salah satunya adalah Desa Wisata Ketingan. Desa Wisata Ketingan terletak di Desa Tirtoadi, Mlati, Sleman, Yogyakarta memiliki potensi sebagai salah satu tujuan destinasi obyek wisata desa yang ada di Yogyakarta, akan tetapi pengembangan desa wisata tersebut masih belum maksimal khususnya dalam hal sosialisasi produk dan strategi pemasaran yang belum prospektif sehingga perlu adanya 
upaya untuk meningkatkan daya tarik wisata desa, seperti yang telah diuraikan oleh Suwarjo (2018), setidaknya terdapat tiga hal yang dapat dilakukan yaitu pertama, pemerintah sebagai fasilitator sekaligus pengambil kebijakan perlu memberikan dukungan dalam melakukan pendampingan dan pelatihan untuk menunjang layanan wisata. Kedua, perlu dibangunnya jejaring dan kerjasama yang lebih intens antara pemerintah daerah khususnya Dinas Pariwisata dan Kebudayaan Kabupaten Sleman dengan pihak swasta (biro jasa travel dan hotel) untuk menyusun dan menawarkan paket kunjungan wisata dengan menyertakan desa wisata ketingan sebagai bagian dari paket wisata yang ditawarkan. Ketiga, perlu dilakukan kembali pertemuan yang lebih intens diantara asosiasi desa wisata yang ada saat ini baik pada tingkat kabupaten maupun tingkat propinsi, dengan tujuan saling memberikan manfaat berupa pengalaman dari masingmasing pengelola desa wisata.

Fasilitas sarana dan pra sarana yang baik memberikan kontribusi yang positif terhadap obyek wisata yang terdapat di Yogyakarta, sehingga memudahkan wistatawan mengunjungi semua obyek wisata tersebut. Kualitas layanan berpengaruh positif terhadap kepuasan pelanggan (Dewa, 2018), Kualitas layanan yang baik kepada wisatawan perlu diperhatikan oleh seluruh pengelola obyek wisata, sehingga wisatawan memperoleh pengalaman positif terhadap obyek wisata yang dikunjunginya. Untuk tercapai hal tersebut perlu didukung oleh pengelolaan manajemen pariwisata yang baik. Pengalaman positif yang dirasakan oleh wisatawan terhadap obyek-obyek wisata yang ada di Yogyakarta ramai diceritakan melalui media sosial seperti Facebook, Instagram, Youtube, WhatsaApp dan lain sebagainya ataupun melalui blog. Kerelaan konsumen untuk membagikan cerita dan pengalaman positif mereka mealui internet merupakan kegiatan yang dikenal dengan istilah electronic word of mouth atau disingkat menjadi e-word of mouth.

Word of mouth merupakan komunikasi mengenai produk dan jasa antara orang-orang yang tidak memiliki ikatan apapun dengan perusahaan yang menyediakan produk dan jasa tersebut Jalilvand et al. (2012). Melalui internet word of mouth menjadi komunikasi menyebar lebih luas sehingga interaksi menjadi lebih jamak meliputi beberapa orang, hal tersebut disebut juga dengan electronic word of mout atau disingkat dengan e-WOM. e-word of mouth memainkan peran yang penting dalam menarik turis di zaman $e$ - commerce saat ini (Litvin et al, 2008). Sebagai contoh Jalilvand, et al. (2012) menemukan bahwa satu dari tiga travelers mengunjungi forum, media sosial, atau komunitas online sebelum memutuskan untuk pergi berwisata, karena mereka percaya bahwa ulasan-ulasan online membantu mereka untuk melakukan keputusan pembelian. Jalilvand et al, (2012) menyebutkan bahwa setidakmya terdapat $34,7 \%$ dari total pembelanjaan online berhubungan dengan travel, dan survey terbaru mengindikasikan bahwa lebih dari $74 \%$ wisatawan membaca kolom komentar dari konsumen lainnya sebagai sumber informasi untuk meyusun rencana perjalanan (Gretzel dan Yoo, 2008).

e-Word of Mouth yang positif akan berkontribusi pada meningkatnya jumlah kunjungan suatu daerah wisata, begitu juga sebaliknya e-word of mouth negatif akan berdampak menurunnya jumlah kunjungan suatu daerah wisata. Setiawan et al, (2014) mengatakan bahwa e-word of mouth dapat mempengaruhi citra daerah kunjungan wisata (destination image). Citra destinasi yang positif diwujudkan dengan kepuasan wisatawan yang tinggi saat melakukan kunjungan wisata mereka, sehingga selanjutnya wisatawan tersebut akan melakukan kunjungan ulang ke obyek wisata yang sama atau memberitahukan kolega mereka mengenai obyek wisata yang mereka kunjungi.

Penelitian ini menyajikan bahwa, banyak sekali faktor lain yang dapat mempengaruhi keputusan konsumen dalam berwisata, tetapi sumber informasi individual ternyata menjadi pengaruh utama yang membentuk persepsi seseorang dalam mengunjungi suatu daerah wisata. Banyak wisatawan yang menggunakan sumber internet dan media online lainnya untuk mendapatkan informasi yang mereka butuhkan (Gursoy dan McCleary, 2004). Penelitian ini bertujuan untuk membuktikan mengenai pengaruh kualitas layanan obyek wisata suatu daerah terhadap citra destinasi desa wisata Ketingan dengan e-word of mouth sebagai variabel yang menjadi mediator.

\subsection{Kajian Pustaka \\ 2.1.1. Kualitas Layanan}

Menurut Tjiptono (2004) dalam Dewa (2018) kualitas layanan merupakan usaha memenuhi keinginan pelanggan dengan mengendalikan tingkat keunggulan yang diharapkan. Menurut Dewa (2018), kualitas layanan pemberi jasa dianggap baik dan memuaskan jika dapat memberikan jasa melampaui harapan konsumen, jika jasa yang diberikan lebih rendah daripada harapan konsumen, maka kualitas pelayanan pemberi 
jasa dianggap buruk. Pada penelitian ini menggunakan dimensi kualitas pelayanan yang diungkapkan oleh Kotler (2016) yaitu pertama tangibles yang didalamnya terdapat rupa fisik dan kelengkapan indikator. Kedua, Reliability atau reliabilitas yaitu keakuratan dalam memberikan pelayanan sesuai dengan yang dijanjikan. Ketiga, Responsiveness yaitu respon pengelola atau karyawan dalam memberikan bantuan kepada konsumen dan memberikan pelayanan yang cepat dan tanggap. Keempat Assurance yang meliputi kemampuan dan pengetahuan karyawan atau pengelola dalam melayani konsumen.

\subsubsection{Elektronik Word of Mouth (e-word of mouth)}

Pentingnya Word of Mouth dalam bisnis telah didiskusikan dan diteliti secara luas, terlebih setelah adanya teknologi internet, merevolusi pengaruh dan distribusi dari WOM (Goldenberg, Libai dan Muller, 2001). Dewasa ini strategi komunikasi pemasaran mengalami perubahan ke arah yang lebih praktis, efektif dan efisien, yaitu melalui media sosial (Shimp, 2010). Paquette (2013) memberikan definisi mengenai media sosial, yaitu aplikasi yang membentuk dasar ideologis dan teknologi web yang dapat memberikan keluasan bagi para penggunanya untuk melakukan penciptaan dam pertukaran konten. Penggunaan media sosial telah berkembang luas, yang dahulu hanya sebagai wadah untuk melakukan interaksi sosial, saat ini menjadi sumber informasi bagi konsumen mengenai produk dan jasa (Paquette, 2013). Kelebihan dari media sosial sebagai strategi komunikasi pemasaran yang efektif yaitu terletak pada kekuatan konten yang digunakan sebagai referensi konsumen untuk memperoleh informasi tentang produk dan jasa layanan. Konten dan percapakan yang kuat pada media sosial dapat menstimulasi perusahaan untuk memanfaatkannya sebagai alat untuk memasarkan produk atau jasa perusahaan tersebut. Kaplan dan Henlein (2010), mengatakan bahwa perusahaan melakukan promosi produk atau jasa mereka melalui media sosial dengan membentuk komunitas, forum atau group online bagi para pelanggan setia.

Ulasan-ulasan para pengguna online mengenai destinasi travel, hotel dan layanan wisata telah menjadi sumber informasi yang penting bagi para wisatawan (Jalilvand, 2012). Data menyebutkan bahwa setiap tahunnya, banyak sekali wisatawan potensial yang melakukan konsultasi melalui ulasan-ulasan online. Ulasan-ulasan tersebut yang memungkinkan terbentuknya komunikasi dua arah melalui teknologi internet sehingga mendorong terbentuknya e-word of mouth.

\subsubsection{Citra Destinasi}

Citra destinasi merupakan gambaran atau persepsi individu terhadap suatu daerah, atau wilayah tertentu (Kurniawan, 2014). Citra destinasi adalah persepsi yang menyeluruh mengenai suatu daerah, yang terbentuk dari proses informasi dari berbagai sumber, pada rentang waktu tertentu (Assael, 2010). Menurut Blain et. al (2005) , citra destinasi merupakan kegiatan pemasaran yang mempromosikan keunggulan dan image positif suatu daerah untuk memberikan pengaruh kepada wisatawan agar mengunjungi daerah tersebut. Ecthner dan Ritchie dalam Kurniawan (2014) menyebutkan bahwa terdapat empat atribut yang membentuk citra destinasi, yaitu atribut karakteristik fungsional, karakteristik fungsional holistik, atribut karakteristik psikologis dan karakteristik psikologis holistik.

\subsubsection{Kualitas Layanan dan e-Word Of Mouth}

Kualitas layanan yang baik dari suatu produk atau jasa akan memberikan pengaruh positif bagi persepsi orang terhadap produk atau jasa tersebut, sehingga akan memicu konsumen untuk menceritakan hal tersebut kepada orang lain melalui sosial media, dan lain-lain. Begitu juga sebaliknya jika seseorang merasakan pengalaman buruk dari kualitas layanan suatu produk atau jasa maka ia akan bercerita mengenai pengalaman yang dirasakannya terhadap orang lain melalui sosial media. Maka dari itu pelanggan yang merasakan kinerja layanan yang mendekati atau melebihi tingkat layanan yang diharapkan, akan sangat mungkin bagi pelanggan untuk melakukan pembelian berulang, tetap loyal dan akan menyebarkan WOM positif (Lovelock, 2010).

Nuryanto (2012) menguji pengaruh kualitas layanan inti dan kualitas layanan tambahan terhadap positive word of mouth kepada siswa SMA St. Louis Semarang dan menemukan bahwa kualitas layanan inti memiliki pengaruh positif dan signifikan terhadap positive word of mouth, sedangkan kualitas layanan tambahan sebagai variabel independen kedua berpengaruh positif tapi tidak signifikan terhadap positive word of mouth.

Berdasarkan kajian teoritis dan penelitian terdahulu maka hipotesis pertama (H1) dalam penelitian ini adalah :

H1: Kualitas Layanan berpengaruh positif terhadap e-word of mouth.

\subsection{5. e-Word of Mouth dan Citra Destinasi}

$e$-word of mouth yang positif memiliki peran dalam meningkatkan minat orang lain 
untuk melakukan kunjungan kepada suatu daerah wisata. Komunikasi e-word of mouth antar wisatawan pada media sosial berpengaruh pada meningkatnya citra destinasi wisata (Suwarduki, dkk, 2016).

Penelitian ini mengadopsi citra destinasi dari teori citra merek. Shimp (2010) memiliki penjelasan mengenai citra merek, yaitu suatu jenis asosiasi yang muncul dibenak konsumen saat mengingat sebuah merek tertentu. Konsumen akan memiliki persepsi terhadap merek tertentu saat melihat, mendengar, membaca dan merasakan merek produk, melalui iklan TV, radio, maupun media cetak. Semakin sering konsumen menemukan atau membicarakan sebuah merek tertentu maka dapat diambil suatu kesimpulan bahwa citra merek lembaga yang mengeluarkan produk tersebut juga semakin kuat.

Majid (2014) menemukan bahwa e-word of mouth memiliki pengaruh yang signifikan terhadap citra merek. Jalilvand (2012) juga menemukan hasil penelitian yang sama yaitu e-word of mouth memiliki pengaruh signifikan terhadap citra merek.

Berdasarkan kajian teoritis dan penelitian terdahulu maka hipotesis kedua $(\mathrm{H} 2)$ dalam penelitian ini adalah :

H2 : e-word of mouth berpengaruh positif terhadap Citra Destinasi.

\subsubsection{Kualitas Layanan dan Citra Destinasi}

Kualitas pelayanan yang baik memiliki makna penting bagi kelangsungan hidup sebuah daerah wisata, karena dapat mempengaruhi citra daerah tersebut. Kualitas layanan yang positif akan meningkatkan citra destinasi yang positif. Menurut Lai et. al (2009) kualitas layanan berpengaruh positif dan signifikan terhadap citra suatu organisasi. Purnama (2006) mengungkapkan bahwa kualitas pelayanan yang terdiri dari reputasi perusahaan, dicerminkan oleh citra perusahaan dan reputasi bisnis. Normasari, dkk (2013) menemukan bahwa kemampuan karyawan untuk memahami kebutuhan pelanggan sangat berpengaruh penting terhadap citra perusahaan.

Berdasarkan kajian teortitis dan penelitian terdahulu, maka hipotesis ketiga (H3) dalam penelitian ini adalah :

H3: Kualitas Layanan berpengaruh positif terhadap Citra Destinasi.

H4: e-word of mouth memediasi pengaruh Kualitas Layanan terhadap Citra Destinasi

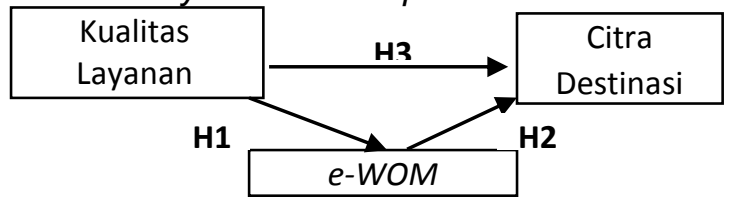

Gambar 1. Model Penelitian

\subsection{Metode Penelitian}

Penelitian ini dilakukan di Desa Wisata Ketingan Desa Tirtoado, Kecamatan Mlati Kabupaten Sleman, Daerah Istimewa Yogyakarta. Terdapat beberapa daya tarik wisata yang menjadi objek dalam penelitian ini, yaitu obyek wisata fauna mengenai keberadaan satwa burung kuntul yang berkembangbiak di dusun ini, obyek wisata flora dengan beragam vegetasi pepohonan, dan budaya tradisional seperti budaya merti bumi, kesenian (jathilan, Pek bunga gejong lesung), tradisi nyadran, tradisi angler, tradisi wiwit, dan kenduri. Data yang digunakan dalam penelitian ini adalah data primer dengan cara menyebarkan kuesioner, dan meminta responden untuk mengisi kuesioner tersebut. Pengukuran setiap variabel dalam kuesioner menggunakan skala Likert dari skala 1 hingga 5. Pemilihan sampel menggunakan metode non-probability sampling yang terdiri dari 120 orang dari seluruh wisatawan yang tergabung dalam grup facebook backpacker Yogyakarta.

Pada penelitian ini, pengujian validitas menggunakan analisis faktor dengan dibantu program SPSS 24. Setelah melakukan uji validitas, selanjutnya yang dilakukan dalam penelitian ini adalah menguji reliabilitas. Pengujian reliabilitas dilakukan dengan cara menghitung cronbach's alpha dengan menggunakan program SPSS 24. Kategori nilai cronbach's alpha adalah sebagai berikut : 1) 0,8-1,0 dikategorikan baik. 2) 0,6-7,9: dikategorikan diterima, dan 3) $<0,6$ dikategorikan buruk. Setelah melakukan uji validitas dan reliabilitas, peneliti melakukan pengujian hipotesis dengan menggunakan SEM melalui program AMOS 18.0.

Hipotesis dari $\mathrm{H} 1, \mathrm{H} 2$, dan $\mathrm{H} 3$ diuji dengan menganalisa significant path pada penelitian, setelah itu $\mathrm{H} 4$ diuji dengan melakukan perbandingan nilai beta pengaruh variabel Kualitas Layanan terhadap Citra Destinasi yang terdapat pada model penelitian (gambar 1) dengan model alternatif (gambar 2). Model alternatif yang dimaksud adalah pengaruh langsung antara variabel Kualitas Layanan terhadap variabel Citra Destinasi tanpa dimediasi oleh variabel e-word of mouth.

Kualitas
Layanan $\longrightarrow$\begin{tabular}{c|} 
Citra \\
Destinasi
\end{tabular}

\section{Gambar 2. Model Alternatif}

Apabila pada model alternatif hasil pengujian menunjukkan nilai beta yang signifikan sedangkan pada model penelitian menunjukkan hal sebaliknya yaitu tidak ada nilai beta yang signifikan, maka mediasi pada model penelitian adalah mediasi sempurna (full 
mediation). Sedangkan apabila model alternatif terdapat nilai beta yang signifikan dan pada model penelitian terdapat juga nilai beta yang signifikan tetapi memiliki nilai yang lebih kecil dibandingkan dengan model alternatif, maka mediasi sebagian atau parsial (partial mediation).

\subsection{Hasil Dan Pembahasan}

\subsubsection{Hasil Penelitian}

Pada pengujian validitas dapat terlihat bahwa semua item pertanyaan pada variabel kualitas layanan, e-word of mouth dan citra destinasi valid, sehingga dapat digunakan dalam pengujian hipotesis.

\section{Tabel 1}

Hasil Uji Validitas Kualitas Pelayanan

\begin{tabular}{|c|c|c|c|}
\hline Kode & $\begin{array}{c}\text { Item } \\
\text { Pertanyaan }\end{array}$ & $\begin{array}{l}\text { Factor } \\
\text { Loading }\end{array}$ & $\begin{array}{c}\text { Keterang } \\
\text { an }\end{array}$ \\
\hline KP1 & $\begin{array}{l}\text { Kemampuan } \\
\text { dan keramahan } \\
\text { penyelanggara } \\
\text { desa wisata } \\
\text { ketingan dalam } \\
\text { memberikan } \\
\text { pelayanan. }\end{array}$ & 0,67 & Valid \\
\hline KP2 & $\begin{array}{l}\text { Daya tanggap } \\
\text { dan kecekatan } \\
\text { penyelenggara } \\
\text { desa wisata } \\
\text { ketingan dalam } \\
\text { melayani setiap } \\
\text { wisatawan }\end{array}$ & 0,62 & Valid \\
\hline KP3 & $\begin{array}{l}\text { Perhatian/atensi } \\
\text { penyelenggara } \\
\text { desa wisata } \\
\text { ketingan dalam } \\
\text { menanggapi } \\
\text { permintaan } \\
\text { wisatawan }\end{array}$ & 0,61 & Valid \\
\hline KP4 & $\begin{array}{l}\text { Memberikan } \\
\text { jaminan } \\
\text { kemanan } \\
\text { kepada } \\
\text { wisatawan }\end{array}$ & 0,58 & Valid \\
\hline
\end{tabular}

Tabel 2

Hasil Uji Validitas e-Word of Mouth

\begin{tabular}{|c|c|c|c|}
\hline Kode & $\begin{array}{c}\text { Item } \\
\text { Pertanyaan }\end{array}$ & $\begin{array}{l}\text { Factor } \\
\text { Loading }\end{array}$ & Ket. \\
\hline EW1 & $\begin{array}{l}\text { Kesenangan } \\
\text { menceritakan } \\
\text { pengalaman } \\
\text { wisata melalui } \\
\text { media sosial }\end{array}$ & 0,94 & Valid \\
\hline EW2 & $\begin{array}{l}\text { Meyakinkan } \\
\text { orang lain untuk } \\
\text { melakukan } \\
\text { kunjungan } \\
\text { wisata ke suatu } \\
\text { daerah melalui } \\
\text { media sosial }\end{array}$ & 0,91 & Valid \\
\hline EW3 & $\begin{array}{l}\text { Kesenangan } \\
\text { merekomendasi } \\
\text { kan kepada } \\
\text { orang lain } \\
\text { mengenai } \\
\text { daerah wisata } \\
\text { melalui media } \\
\text { sosial }\end{array}$ & 0,91 & Valid \\
\hline
\end{tabular}

Tabel 3

Hasil Uji Validitas Citra Destinasi

\begin{tabular}{|c|l|c|c|}
\hline Kode & $\begin{array}{c}\text { Item } \\
\text { Pertanyaan }\end{array}$ & $\begin{array}{c}\text { Factor } \\
\text { Loading }\end{array}$ & Ket. \\
\hline CD1 & $\begin{array}{l}\text { Kualitas jasa } \\
\text { dan fasilitas } \\
\text { wisata yang } \\
\text { ditawarkan }\end{array}$ & 0,71 & Valid \\
\hline CD2 & $\begin{array}{l}\text { Keandalan } \\
\text { jasa dan } \\
\text { fasilitas } \\
\text { wisata yang } \\
\text { ditawarkan }\end{array}$ & 0,65 & Valid \\
\hline CD3 & $\begin{array}{l}\text { Manfaat jasa } \\
\text { dan fasilitas } \\
\text { yang } \\
\text { dirasakan }\end{array}$ & 0,62 & Valid \\
\hline CD & $\begin{array}{l}\text { Harga jasa } \\
\text { dan fasilitas } \\
\text { wisata yang } \\
\text { ditawarkan }\end{array}$ & 072 & Valid \\
\hline Proses & & \\
selanjutnya & & \\
\hline
\end{tabular}

Proses selanjutnya adalah melakukan uj reliabilitas dengan menggunakan metode cronbach's alpha. Pengujian reliabilitas mendapatkan hasil bahwa semua variabel dalam penelitian ini, yaitu kualitas pelayanan, e-word of mouth dan citra destinasi adalah reliabel.

Tabel 4

Hasil Uji Reliabilitas

\begin{tabular}{|c|c|c|}
\hline Variabel & $\begin{array}{c}\text { Cronbach } \\
\text { alpha }\end{array}$ & Kategori \\
\hline Kualitas Pelayanan & 0,77 & $\begin{array}{c}\text { Reliabilit } \\
\text { as baik }\end{array}$ \\
\hline E-WORD OF MOUTH & 0,82 & $\begin{array}{c}\text { Reliabilit } \\
\text { as baik }\end{array}$ \\
\hline Citra Destinasi & 0,72 & $\begin{array}{c}\text { Reliabilit } \\
\text { as baik }\end{array}$ \\
\hline
\end{tabular}

Setelah uji reliabilitas dan ditemukan bahwa setiap variabel dalam penelitian ini memiliki reliabilitas baik, sehingga dapat dilakukan pengujian model fit untuk menentukan kesesuaian model penelitian dengan data. Pada penelitian ini menunjukkan bahwa secara garis besar model penelitian memiliki goodness of fit cukup baik, maka dari itu pengujian hipotesis dapat dilakukan dengan model penelitian ini.

\section{Tabel 5}

Hasil Uji Model Fit

\begin{tabular}{|c|c|c|c|}
\hline Kriteria & $\begin{array}{c}\text { Cut of } \\
\text { Value }\end{array}$ & Hasil & Evaluasi \\
\hline Chi square; df & 214,48 & 185,42 & Baik \\
\hline CMIN/DF & $\leq 2,00$ & 1,115 & Baik \\
\hline GFI & $\geq 0,90$ & 0,872 & Cukup \\
\hline AGFI & $\geq 0,90$ & 0,804 & Cukup \\
\hline TLI & $\geq 0,90$ & 0,954 & Baik \\
\hline CFI & $\geq 0,90$ & 0,975 & Baik \\
\hline RMSEA & $\leq 0,08$ & 0,079 & Baik \\
\hline
\end{tabular}

Nilai uji chi square pada uji model fit memperoleh angka sebesar 185,42, hal ini menunjukkan bahwa nilai masih dibawah chi 
square tabel yaitu 214,48 sehingga dapat disimpulkan bahwa model memiliki unsur parsimoni. Nilai CMIN/DF berada dibawah standar, yaitu 1,115 dengan batas umum adalah 2,00. Hal tersebut mendukung hasil dari nilai chi square bahwa model penelitian memiliki unsur parsimoni.

Nilai AGFI (Adjusted Goodness of Fit) dan Hasil perhitungan Nilai GFI (Goodness of Fit) tidak memenuhi batas minimum tapi masih dapat dikatakan cukup, sehingga menunjukkan bahwa nilai kesesuaian model dengan data dalam penelitian ini masih dalam batas marginal dan dapat disimpulkan bahwa nilainilai incremental fit menunjukkan hasil yang secara umum baik. Nilai RMSEA sebesar 0,079 memenuhi kriteria penerimaan model karena berada diantara batas atas dan batas bawah. Hasil dalam uji model fit menunjukkan bahwa model penelitian dengan data sudah sesuai dan model penelitian memiliki unsur parsimoni.

Pengujian hipotesis $\mathrm{H} 1, \mathrm{H} 2$ dan $\mathrm{H} 3$ dilakukan pengujian melalui significant path pada penelitian, lalu hipotesis $\mathrm{H} 4$ dilakukan pengujian dengan membandingkan nilai beta pada pengaruh variabel kualitas layanan terhadap variabel citra destinasi. Tabel 6 menunjukkan hasil pengujian hipotesis.

Tabel 6

Hasil Uji Hipotesis

\begin{tabular}{|c|c|c|c|c|}
\hline No. & Hipotesis & $\begin{array}{l}\text { Standardized } \\
\text { Regression } \\
\text { on Weights }\end{array}$ & $\mathbf{P}$ & Ket. \\
\hline $\mathrm{H} 1$ & $\begin{array}{l}\text { Kualitas } \\
\text { layanan } \\
\text { berpengar } \\
\text { uh positif } \\
\text { terhadap } \\
\text { e-Word of } \\
\text { Mouth }\end{array}$ & 0,520 & $<0,05$ & $\begin{array}{l}\text { Hipotesis } \\
\text { diterima }\end{array}$ \\
\hline $\mathrm{H} 2$ & $\begin{array}{l}\text { e-Word of } \\
\text { Mouth } \\
\text { berpengar } \\
\text { uh positif } \\
\text { terhadap } \\
\text { citra } \\
\text { destinasi }\end{array}$ & 0,515 & $<0,05$ & $\begin{array}{l}\text { Hipotesis } \\
\text { diterima }\end{array}$ \\
\hline $\mathrm{H} 3$ & $\begin{array}{l}\text { Kualitas } \\
\text { layanan } \\
\text { berpengar } \\
\text { uh positif } \\
\text { terhadap } \\
\text { citra } \\
\text { destinasi }\end{array}$ & 0,530 & $<0,05$ & $\begin{array}{l}\text { Hipotesis } \\
\text { diterima }\end{array}$ \\
\hline
\end{tabular}

Tabel 7

Hasil Pembanding Mediasi

\begin{tabular}{|c|c|c|c|c|}
\hline No. & Hipotesis & $\begin{array}{c}\text { Standardized } \\
\text { Regression on } \\
\text { Weights }\end{array}$ & $\mathrm{P}$ & Ket. \\
\hline $\mathrm{H3a}$ & $\begin{array}{l}\text { Kualitas layanan } \\
\text { berpengaruh } \\
\text { positif terhadap } \\
\text { citra destinasi } \\
\text { yang dimediasi } \\
\text { oleh e-word of } \\
\text { mouth }\end{array}$ & 0,530 & $<0,05$ & $\begin{array}{l}\text { Hipotesis } \\
\text { diterima }\end{array}$ \\
\hline $\mathrm{H} 3 \mathrm{~b}$ & $\begin{array}{l}\text { Kualitas layanan } \\
\text { berpengaruh } \\
\text { positif terhadap } \\
\text { citra destinasi }\end{array}$ & 0,377 & $<0,05$ & $\begin{array}{l}\text { Hipotesis } \\
\text { diterima }\end{array}$ \\
\hline
\end{tabular}

\subsubsection{Pembahasan Penelitian}

Hasil uji hipotesis pada tabel 6 menunjukkan bahwa kualitas layanan berpengaruh positif terhadap e-word of mouth $(\beta=0,520 ; P<0,05)$. Hasil tersebut sejalan dengan hipotesis pertama dari penelitian ini. Sehingga dapat diartikan bahwa semakin tinggi kualitas layanan maka akan memberikan e-word of mouth yang semakin positif. Begitu pula sebaliknya semakin rendah kualitas layanan akan berdampak pada e-word of mouth yang negatif. Hal tersebut juga senada dengan penelitian terdahulu yang diungkapkan oleh Lovelock (2010) yangmenyatakan bahwa pelanggan yang merasakan kinerja layanan yang mendekati atau melebihi tingkat layanan yang diharapkan, akan sangat mungkin bagi pelanggan untuk melakukan pembelian berulang, tetap loyal dan akan menyebarkan WOM positif.

e-word of mouth berpengaruh positif terhadap citra destinasi $(\beta=0,520 ; P<0,05)$. Hasil hipotesis ini sejalan dengan hipotesis kedua dari penelitian ini, jadi semakin positif $e$ word of mouth maka akan meningkatkan citra destinasi suatu daerah. Begitu juga sebaliknya, jika e-word of mouth semakin negatif maka akan menurunkan citra destinasi suatu daerah. Hal ini sejalan dengan Suwarduki,dkk (2016) yang menyatakan bahwa Komunikasi e-word of mouth antar wisatawan pada media sosial berpengaruh pada meningkatnya citra destinasi wisata.

Kualitas layanan berpengaruh positif terhadap citra destinasi dengan nilai $\beta=0,530$ dan $P<0,05$. Hasil tersebut sesuai dengan hipotesis ketiga dari peneliti, yang berarti bahwa semakin tinggi tingkat kualitas layanan yang diberikan kepada wisatawan akan berpengaruh meningkatnya citra destinasi suatu daerah di benak wisatawan. Hal ini juga sesuai dengan penelitian terdahulu yang dilakukan Lai et. al (2009), Purnama (2006) 
dan Normasari (2013) yang menyatakan bahwa kualitas pelayanan dapat berpengaruh positif dan signifikan terhadap citra suatu organisasi.

Pada tabel 7 terlihat hasil hubungan antara kualitas layanan terhadap citra destinasi tanpa dimediasi oleh $e$-word of mouth yaitu $\beta=$ 0,377 dengan $\mathrm{P}<0,05$. Hal ini menunjukkan bahwa kualitas layanan tetap berpengaruh positif dan signifikan terhadap kualitas layanan tanpa e-word of mouth menjadi mediatornya. Akan tetapi nilai signifikansinya lebih kecil jika dimediasi oleh e-word of mouth. Hal ini berarti e-word of mouth menjadi mediasi yang sepenuhnya untuk hubungan antara kualitas layanan terhadap citra destinasi. Semakin tinggi nilai kualitas layanan berarti semakin positif e-word of mouth, sehingga makin meningkat citra destinasi suatu daerah.

\subsection{Kesimpulan Dan Saran}

Berdasarkan pembahasan dalam penelitian dapat diambil kesimpulan bahwa kualitas layanan dapat mempengaruhi e-word of mouth secara positif sehingga semakin tinggi kualitas layanan maka semakin positif $e$ word of mouth. Hal ini berarti, Desa wisata ketingan memiliki kualitas layanan yang dianggap baik dan memuaskan wisatawan sehingga para wisatawan memberikan penilaian dan ulasan-ulasan positif mengenai desa wisata tersebut pada media sosial.

$e$-word of mouth mempengaruhi citra destinasi desa wisata Ketingan secara positif, sehingga semakin positif e-word of mouth maka semakin tinggi citra destinasi desa wisata Ketingan. E-word of mouth yang positif mengenai desa wisata Ketingan memberikan peningkatan citra destinasi desa wisata tersebut di mata para wisatawan. Sehingga tempat wisata dan fasilitas wisata yang berada di desa wisata Ketingan dipersepsikan memiliki citra yang baik, yang akan menarik minat berkunjung wisatawan.

Kualitas layanan dapat mempengaruhi citra destinasi desa wisata Ketingan secara positif, sehingga semakin tinggi kualitas layanan maka semakin tinggi citra destinasi desa wisata Ketingan di benak konsumen. Hal tersebut dapat terjadi karena kualitas layanan yang diberikan oleh pengelola desa wisata Ketingan dirasa baik oleh wisatawan sehingga persepsi wisatawan mengenai desa wisata Ketingan adalah baik dengan fasilitas yang memadai dan lingkungan alam yang menyenangkan wisatawan.

e-word of mouth memediasi secara penuh hubungan antara kualitas layanan terhadap citra destinasi desa wisata Ketingan. Semakin positif e-word of mouth berdampak semakin tinggi pula pengaruh kualitas layanan terhadap citra destinasi desa wisata Ketingan. Hal tersebut terjadi karena wisatawan menjadikan kualitas layanan sebagai bahan pertimbangan melalui ulasan-ulasan para wisatawan lainnya di media sosial mengenai destinasi travel, hotel dan layanan wisata desa wisata Ketingan, sehingga meningkatkan persepsi wisatawan mengenai citra desa wisata Ketingan.

Menurut hasil dari penelitian ini, peneliti menyarankan bagi pengelola wisata daerah atau kepala desa untuk terus meningkatkan kualitas layanan yang terdapat pada tempat wisata desa sehingga mampu memberikan pengalaman yang baik bagi para wisatawan. Pengalaman tersebut akan mendorong wisatawan untuk memberikan ulasan-ulasan yang baik mengenai tempat wisata dan meningkatkan citra destinasi daerah. Hasil penelitian ini berlum dapat menggenalisir variabel-variabel yang akan diakibatkan dari pengaruh kualitas layanan dan e-word of mouth. Maka dari itu, saran untuk penelitian selanjutnya agar menambahkan variabel minat berkunjung sebagai variabel dependen. Citra destinasi yang baik memungkinkan untuk memberikan peningkatan bagi minat berkunjung wisatawan yang kemudian akan meningkatkan pendapatan daerah.

\section{Daftar Pustaka}

[1] Assael, H., (2010), Consumer Behavior and Marketing Action. Pws-Kent Publishing Company, Inc.

[2] Blain, C., Levy, S., dan Ritchie, J.R.B., (2005), Destination Branding : Insights and Practices From Destination Management Organization, Journal of Travel Research, Vol.43, No.4.

[3] Dewa, Chriswardana Bayu., (2018), Pengaruh Kualitas Pelayanan dan Promosi Penjualan Jasa Grabcar Terhadap Kepuasan Pelanggan, Jurnal Persepektif, Vol. XVI, No.1.

[4] Goldenberg, J., Libai.B.,\& Muller,E. (2001). Talk of the network: A Complex System Look at The Underlying Process of Word of Mouth, Marketing Letters, 12(3), 211223.

[5] Gretzel, U., \& Yoo,K. (2008). Use and Impact of Online Travel Reviews, Information and Communication Technologies in Tourism, 2008, (pp.3546), New York : Springer-Verlag.

[6] Gursoy, D., \& McCleary, K, W. (2004). An Integrative Model of Tourists' Information Search Behavior, Annals of Tourism Research, 31, 353-373. 
[7] Ika, Aprilia. (2019). Kunjungan Wisatawan ke DIY Ditarget Naik, Agen Travel "Online" Ikut Berbenah. Diambil dari: https://regional.kompas.com/read/2019/03/ 01/13404661/kunjungan-wisatawan-ke-diyditarget-naik-agen-travel-online-ikutberbenah. (17 Juli 2019).

[8] Jalilvand, M.R. Ebrahimi, A., \& Samiei, N. (2012). Electronic Word of Mouth Effects on Tourists' Attitudes Toward Islamic Destination and Travel Intention: an Empirical Study in Iran, Procedia-Sosial and Behavioral Sciences, 81 (2013), 484489.

[9] Kaplan, A.M., dan Haenlein, M., (2010), Users of the World, Unite! The Challenges and Opportunities of Social Media. Bus, Horiz. Vol. 53.

[10]Kotler, P., dan Keller, K.L., (2016), Marketing Management, Prentice Hall Published, New Jersey.

[11]Kurniawan, C.J., (2014), Studi Deskriptif Destination Image Kota Malang Menurut Perspektif Wisatawan Surabaya. Jurnal IImiah Mahasiswa Universitas Surabaya, Vol. 3, No.2.

[12] Lai, Fujun., Griffin, M., \& Babin, B.J., (2009), How Quality, Value Image, and Satisfaction Create Loyalty at a Chinese telecom. Journal of Business Research. 62 (2009). 980-986.

[13] Litvin, S.W., Goldsmith, R.E., \& Pan, B. (2008). Electronic Word of Mouth in Hospitality and Tourism Management. Tourism Management, 29(3), 458-468.

[14] Lovelock, Christoper. (2010), Pemasaran Jasa Jilid 1 Edisi Ketujuh. Jakarta: Erlangga.

[15] Majid, Nurkholish. (2014), Analisis Pengaruh Electronic Word of Mouth
Terhadap Brand Image dan Dampaknya pada Niat Beli Smartphone Samsung di Kota Malang. Jurnal IImiah Mahasiswa $F E B$, Vol.2., No.2.

[16] Normasari, S., Srikandi, K., \& Andriani, K. (2013), Pengaruh Kualitas Pelayanan Terhadap Kepuasan Pelanggan, Citra Perusahaan dan Loyalitas Pelanggan, Jurnal Administrasi Bisnis, Vol.6., No.2.

[17] Nuryanto, Y.J., (2012), Kualitas Layanan dan Positive Word of Mouth, Jurnal Dinamika Manajemen, Vol.3., No.2., 148154.

[18] Paquette, H., (2013), Social Media as a Marketing Tool: A Literature Review. Journal of University of Rhode Island. 126.

[19] Purnama, N., (2006), Manajemen Kualitas Edisi Pertama. Yogyakarta : EKONISIA.

[20] Setiawan, P.Y., (2014), The Effect of eWOM on Destination Image, Satisfaction and Loyalty, International Journal of Business and Management Invention, Vol. 3 , No.1.

[21] Shimp, T.A., (2010), Management Strategy., New Jersey: Prentice Hall.

[22] Suwarjo, (2018), Strategi Pengelolaan Potensi Lokal dalam Pengembangan Desa Wisata Ketingan Desa Tirtoado Kecamatan Mlati Kabupaten Sleman, Populika Jurnal IImu Sosial dan IImu Politik, Vol. VI., No.1.

[23] Suwarduki, P.R., Edy, Y.\& Kholid. M., (2016), Pengaruh Electronic Word of Mouth Terhadap Citra Destinasi Serta Dampaknya Pada Minat dan Keputusan Berkunjung, Jurnal Administrasi Bisnis, Vol.2 Agustus 2016. 